\title{
MDM2 negatively regulates the human telomerase RNA gene promoter
}

\author{
Jiangqin Zhao ${ }^{1}$, Alan Bilsland ${ }^{2}$, Katrina Jackson ${ }^{2}$ and W Nicol Keith*2
}

Address: ${ }^{1}$ Department of Cell Physiology and Pharmacology, Faculty of Medicine and Biological Sciences, University of Leicester, Leicester, LE1 9HN, UK and ${ }^{2}$ Centre for Oncology \& Applied Pharmacology, University of Glasgow, Cancer Research UK Beatson Laboratories, Garscube Estate, Switchback Rd, Glasgow G61 1BD, UK

Email: Jiangqin Zhao - jz27@le.ac.uk; Alan Bilsland - a.bilsland@beatson.gla.ac.uk; Katrina Jackson - k.jackson@beatson.gla.ac.uk; W Nicol Keith* - n.keith@beatson.gla.ac.uk

* Corresponding author

Published: 18 January 2005

BMC Cancer 2005, 5:6 doi:10.1 186/147|-2407-5-6
Received: 23 September 2004

Accepted: 18 january 2005

This article is available from: http://www.biomedcentral.com/I47I-2407/5/6

(c) 2005 Zhao et al; licensee BioMed Central Ltd.

This is an Open Access article distributed under the terms of the Creative Commons Attribution License (http://creativecommons.org/licenses/by/2.0), which permits unrestricted use, distribution, and reproduction in any medium, provided the original work is properly cited.

\begin{abstract}
Background: We have previously demonstrated that NF-Y and SpI interact with the human telomerase RNA (hTR) promoter and play a central role in its regulation. We have also shown that PRB activates the $h T R$ promoter, but the mechanism of pRb directed activation is unknown. It has recently been reported that $\mathrm{PRB}$ induces $\mathrm{Spl}$ activity by relieving inhibition mediated by $\mathrm{mdm} 2$. The aim was to investigate possible roles for $\mathrm{mdm} 2$ in $\mathrm{hTR}$ promoter regulation.
\end{abstract}

Methods: Chromatin immunoprecipitation was used to determine binding of $\mathrm{mdm} 2$ to the hTR promoter. Transfection and luciferase assays were used to investigate $\mathrm{mdm} 2$ repression of the promoter activity and interaction with known transcriptional modulators.

Results: Here we show using chromatin immunoprecipitation that $\mathrm{mdm} 2$ specifically binds the hTR promoter in vivo. Transient co-transfection experiments using an hTR promoter luciferase reporter construct show that hTR promoter activity is inhibited by over-expression of $\mathrm{mdm} 2$ in 5637 bladder carcinoma cells ( $\mathrm{p} 53$ and pRB negative, low $\mathrm{mdm} 2$ ). Titration of $\mathrm{mdm} 2$ was able to antagonise activation of $\mathrm{hTR}$ promoter activity mediated by PRB or SpI over-expression, although in the presence of $\mathrm{pRB}, \mathrm{mdm} 2$ could not repress promoter activity below basal levels. Using an SpI binding site mutation construct we showed that $\mathrm{mdm} 2$ repression did not absolutely require $\mathrm{Spl}$ binding sites in the hTR promoter, suggesting the possibility of pRB/SpI independent mechanisms of repression. Finally, we show that NF-Y mediated transactivation of the hTR promoter was also suppressed by $\mathrm{mdm} 2$ in a dose-dependent manner.

Conclusions: These studies suggest that $\mathrm{mdm} 2$ may inhibit the hTR promoter by multiple mechanisms. Mdm2 may directly repress activation by both PRB and SpI, or activation by NF-Y. Furthermore, the ability of $\mathrm{mdm} 2$ to interact and interfere with components of the general transcription machinery might partly explain the general repressive effect seen here. Elucidation of new regulators affecting hTR basal promoter activity in cancer cells provides a basis for future studies aimed at improving our understanding of the differential hTR expression between normal and cancer cells. 


\section{Background}

Telomerase is a ribonucleoprotein complex that consists of an essential RNA molecule, hTR, with a template domain for telomeric DNA synthesis and of a catalytic protein, hTERT, with reverse transcriptase activity. Functional telomerase is minimally composed of both hTR and hTERT $[1,2]$. The transcriptional control of these two genes is a major step in the regulation of telomerase expression in human cells, with high expression of both genes detected in cancer cells relative to normal cells [3-6]. Several groups have recently reported transcriptionally targeted cancer gene therapy strategies based on the differential activities of hTR and hTERT promoters between normal and cancer cells [7-11]. Thus, investigation of the activating and repressive mechanisms of telomerase gene transcription has become an area of intense interest in cancer research.

The molecular regulation of hTR gene transcription in cancer cells remains poorly understood. The previously identified core promoter region in the hTR gene has several features utilised by the basal RNA PolII transcription machinery, including one CCAAT-box and four Sp1 sites termed Sp1.1-Sp1.4. The activity of the hTR promoter is controlled by NF-Y, Sp1 and Sp3 in bladder cancer cells in vitro and we have recently shown that an $\mathrm{Sp} 1$ site mutation in the hTR promoter detected in a blood sample taken from a paroxysmal nocturnal haemoglobinuria (PNH) patient can alter core promoter activity in vitro, raising the possibility that mutation might affect hTR gene transcription in hematopoietic cells in vivo [12-14]. Several other known transcriptional regulators, including the retinoblastoma protein $\mathrm{pRB}$, are able to affect hTR transcription in the experimental setting of over-expression $[12,13]$.

The mechanism whereby pRB activates hTR remains unknown though pRB is not known to interact directly in a specific fashion with DNA, relying instead on recruitment to genes through interaction with other transcriptional regulators including $\mathrm{Sp} 1$ and $\mathrm{mdm} 2$. The recent finding that $\mathrm{pRB}$ induces Sp1 activity by binding to mdm 2 resulting in the physical release of $\mathrm{Sp} 1$ from $\mathrm{mdm} 2$ and enhancement of its binding to consensus sequence implies that mdm 2 might inhibit promoters such as hTR that are positively regulated by $\mathrm{pRb}$ and $\mathrm{Sp} 1$ [15]. In this study, we investigated regulation of hTR reporter constructs by Sp1, pRb, NF-Y and mdm 2 and performed chromatin immunoprecipitation (ChIP) assays to determine whether $\mathrm{mdm} 2$ plays a role in hTR regulation in the p53 and $\mathrm{pRb}$ negative bladder cancer cell line 5637 which also expresses relatively low levels of $\mathrm{mdm} 2$ [16]. We found that mdm2 interacts with the hTR promoter in vivo and that mdm2 expression can down-regulate hTR promoter activity and suppress pRb, Sp1 and NF-Y-mediated trans- activation. Sp1 sites within the hTR core promoter were not absolutely required for this negative effect. These studies demonstrate that hTR transcription is dominantly repressed by mdm 2 through functional, and possibly physical, interactions with the hTR promoter complex.

\section{Methods \\ Materials and cell culture}

Antibodies to Sp1, TFIIB and mdm2 were purchased from Santa Cruz Biotechnology Inc. (Santa Cruz, CA). Rabbit polyclonal antibodies directed against NF-YA, B and C were obtained from R. Mantovani (University of Milan, Milan, Italy). The 5637 cell line, originally established from the primary bladder carcinoma of a 68-year-old man in 1974, was purchased from DSMZ (No: ACC 35). 5637 cells were maintained at $37^{\circ} \mathrm{C}$ in $5 \% \mathrm{CO}_{2}$ in 1640 medium supplemented with $10 \%$ foetal bovine serum, penicillin, and streptomycin.

\section{Plasmid construction and site-directed mutagenesis}

Construction of the promoter fragment hProm867 and subcloning as an Xho I/Hind III fragment in the luciferase reporter pGL3-Basic (Promega, Madison, WI) was previously reported [17]. The reporter contains an 867 bp fragment of the hTR promoter. For generation of the Sp1 site mutation construct a two step cloning strategy was used to prevent unexpected mutations in luciferase reporter vectors; (i) an hTR 176 bp fragment (2923 wt, spanning from -107 to +69 bp) was cloned into the Xho I/Hind III sites in pCR-Script ${ }^{\mathrm{TM}}$ plasmid vector (Stratagene, La, Jolla CA), which was used as template for PCR mutagenesis using a QuikChange $^{\mathrm{TM}}$ site-directed mutagenesis kit (Stratagene, La, Jolla CA) following the manufacturer's instructions. (ii) All mutation fragments were reconstructed into the Xho I/Hind III sites of pGL3-basic vectors and verified by DNA sequencing. The multiple-site mutation construct was generated in several separate PCR reactions as previously described [12].

\section{Transfection and dual-luciferase reporter assay}

The hTR promoter plasmids containing firefly luciferase reporters were cotransfected into tumour cells with an internal Renilla luciferase control, pRL-SV40 (Promega) using Superfect Transfection Reagent (Qiagen) as previously described [12,13]. 5637 cells were cotransfected with $0.5 \mu \mathrm{g}$ of expression vectors encoding wild-type NFYA, B and C (kindly donated by Dr R. Mantovani [18]), titrations of $\mathrm{Sp} 1, \mathrm{pRb}$ and $\mathrm{mdm} 2,3 \mu \mathrm{g}$ of the plasmids containing the luciferase reporter gene and $0.5 \mu \mathrm{g}$ of pRLSV40 plasmid for control of transfection efficiency. The total amount of DNA was kept constant at $10 \mu \mathrm{g}$ with Salmon sperm DNA. The activity of both firefly and Renilla luciferase was determined $48 \mathrm{~h}$ later using the Dual Luciferase Assay kit (Promega). A minimum of three independent transfections were performed in duplicate and 


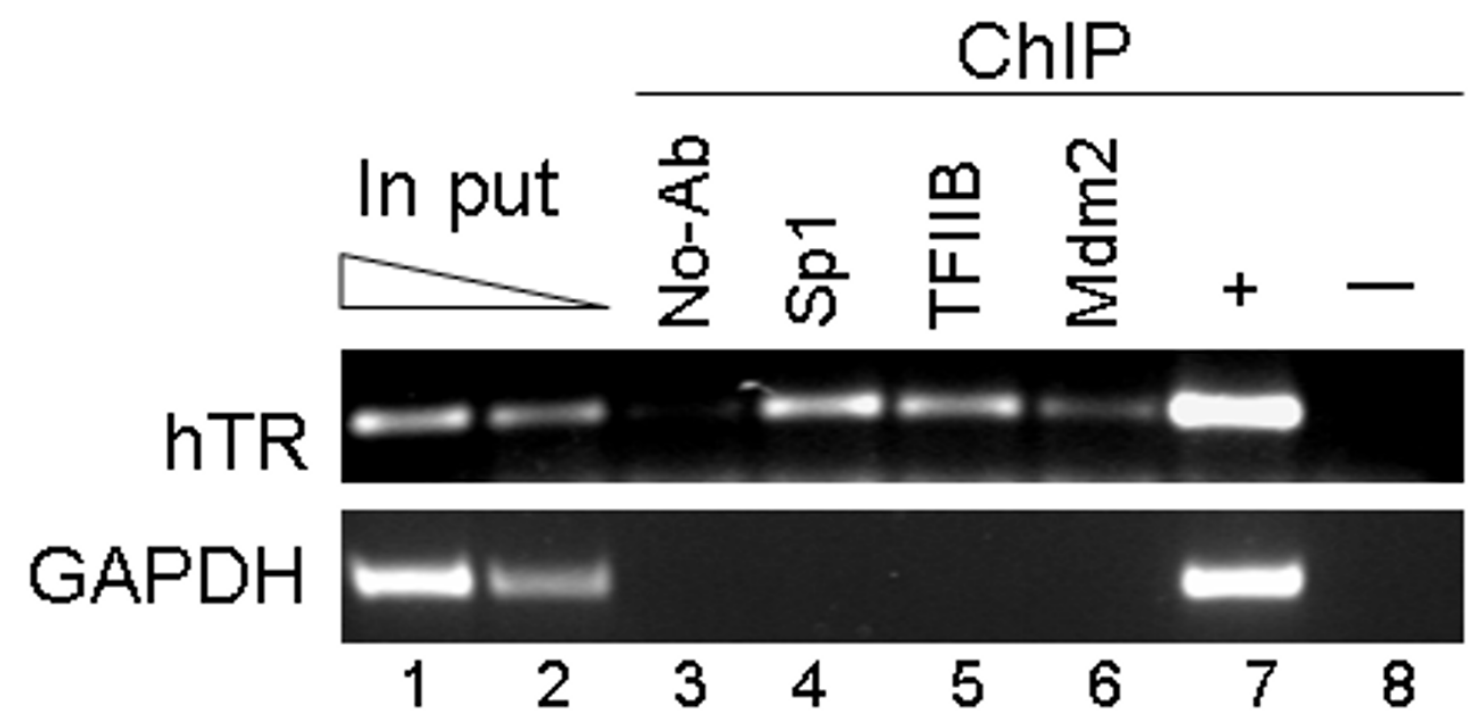

Figure I

mdm2 interacts with the hTR core promoter in vivo. Formaldehyde cross-linked chromatin was prepared from 5637 cells and immunoprecipitated with antibodies to SpI (lane 4), TFIIB (lane 5) and mdm2 (lane 6), or in the absence of antibody (lane 3). PCR detection of DNA sequences immunoprecipitated with each antibody is shown in these lanes. PCR was performed with specific primers for the hTR promoter and for the GAPDH coding region as a negative control. A sample representative of the total input chromatin (input DNA lanes I and 2) was included in the PCR analysis. Lanes 7 and 8 show PCR positive and negative controls. Chromatin immunoprecipitation experiments were repeated three times and PCR analysis of individual experiments was also performed at least twice.

specific hTR promoter activity was normalized to protein as described elsewhere $[12,13]$.

\section{Chromatin immunoprecipitation assays}

Formaldehyde cross-linking and chromatin immunoprecipitation were performed as described previously [19]. In brief, 5637 cell cultures were treated with formaldehyde for $10 \mathrm{~min}$ followed by the addition of glycine to a final concentration of $0.125 \mathrm{M}$. Cells were then washed twice with cold PBS and were resuspended in lysis buffer (1\% SDS, 10 mM EDTA, $50 \mathrm{mM}$ Tris-HCI, pH 8.1) with a proteinase inhibitor. After brief sonication to fragment the DNA with an average fragment size of $500 \mathrm{bp}$, the DNA fragments crosslinked to the proteins were enriched by immunoprecipitation with specific antibodies. A "No-Ab" sample was included as a negative control for the immunoprecipitation step. After reversal of the crosslinks and DNA purification, the extent of enrichment was monitored by PCR amplification of promoters using forward and reverse primers to the hTR (5'-TACGCCCTTCTCAGTTAGGGTTAG-3' and 5'-AGCCCGCCCGAGAGAGTGAC$\left.3^{\prime}\right)$ gene promoter fragments [Zhao, 2003 \#9] and to the GAPDH coding region as a negative control (5'-TGAAGGTCGGAGTCAACGGATTTGGT-3' and 5'-CATGTGGGCCATGAGGTCCACCAC-3'). The PCR product was separated by agarose gel electrophoresis. The input 
sample was processed with the rest of the samples from the point at which the cross-links were reversed. All chromatin immunoprecipitation experiments were repeated three times and PCR analysis of individual experiments was also performed at least twice.

\section{Results}

Mdm2 interacts with hTR core promoter in vivo

Regulation of hTR promoter activity by pRb and Sp1 suggests that $\mathrm{mdm} 2$ might also play a role in hTR promoter regulation. To investigate whether $\mathrm{mdm} 2$ protein targets the hTR promoter in vivo, we performed chromatin immunoprecipitation experiments using antibodies to Sp1, TFIIB and mdm2. The presence of the hTR promoter in chromatin immunoprecipitates was detected by semiquantitative PCR. Antibodies to Sp1 and TFIIB, both of which have previously been detected at the hTR promoter in chromatin immunoprecipitation, and to $\mathrm{mdm} 2$ all precipitated the hTR core promoter DNA sequence but failed to precipitate the negative control GAPDH coding sequence from 5637 cells (Fig. 1). These results establish that $\mathrm{mdm} 2$ binds the hTR core promoter in vivo.

\section{Mdm2 represses the $h T R$ promoter and $p R b$ and $S p I$ mediated transactivation}

To address whether mdm 2 affects the activity of the hTR promoter in vitro, a luciferase reporter carrying an $867 \mathrm{bp}$ fragment of the hTR promoter $(-798 /+69)$ was used in transient co-transfections with a full-length $\mathrm{mdm} 2$ expression vector. As shown in Fig. 2, the hTR promoter was repressed by $\mathrm{mdm} 2$ in a dose dependent manner. Promoter activity under maximal repression by $\mathrm{mdm} 2$ was $42 \%$ of basal activity using $3 \mu \mathrm{g}$ of the $\mathrm{mdm} 2$ expression vector.

Mdm2 has been shown to interact with the transcription factor $S p 1$ in vitro and in vivo and to inhibit transactivation of Sp1-activated promoters $[15,20]$. We next tested whether mdm 2 could interfere with $\mathrm{Sp} 1$ and pRb mediated transactivation of the hTR promoter. The 5637 cell line expresses low levels of mdm 2 and does not express functional p53 or pRb [16]. As shown in Fig. 3A, and as previously reported, co-transfection of 5637 cells with Sp1 increased hTR promoter activity 2 -fold relative to the vector control. Mdm2 overexpression was able to repress Sp1 mediated activation at all mdm2 concentrations, with Sp1 mediated induction completely abolished in the presence of $1 \mu \mathrm{g} \mathrm{mdm} 2$. Even in the continued presence of Sp1 overexpression, at high $\mathrm{mdm} 2$ concentrations promoter activity was reduced to sub-basal levels similar to those observed with mdm2 alone. Similarly, pRb overexpression led to a 3.75-fold induction of promoter activity that could be repressed in a dose dependent manner by titration of $\mathrm{mdm} 2$ (figure $3 \mathrm{~B}$ ). Interestingly though, at the plasmid concentrations used, even the

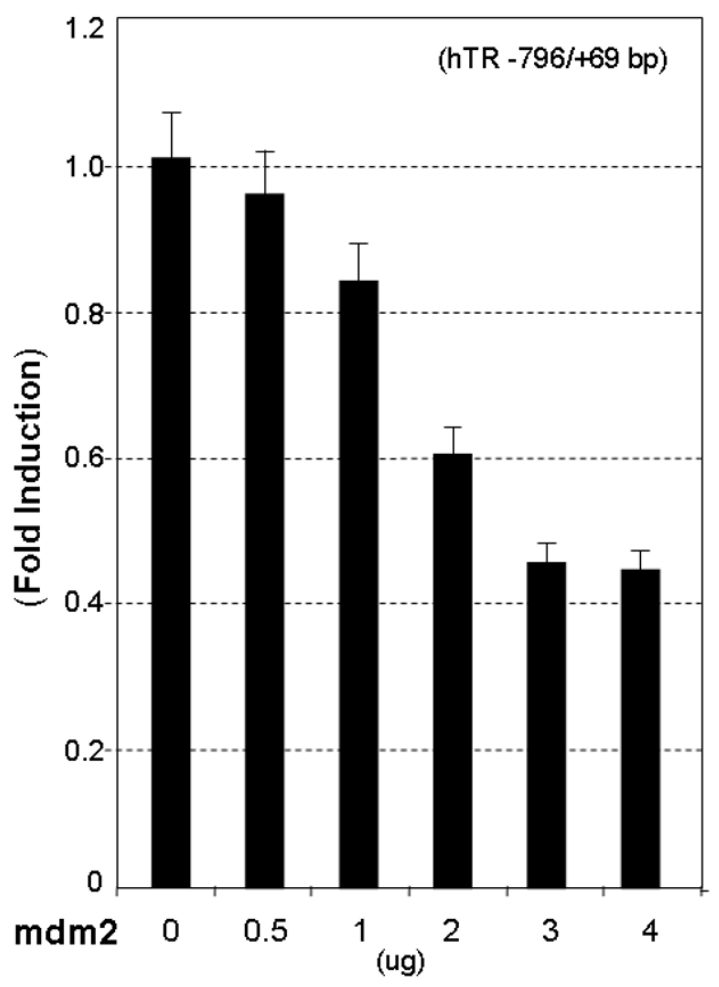

Figure 2

mdm 2 represses $h T R$ promoter activity. The $p R B / p 53$ negative cell line 5637 were co-transfected with I.5 $\mu \mathrm{g}$ of the pLh2023(-796/+69) construct and increasing amounts of mdm2 expression vector (from 0.5 to $4.0 \mu \mathrm{g}$ ). Total input DNA amount for transfection was adjusted with Salmon Sperm DNA to ensure a constant amount in all transfections. After 48 hour of culture, cells were harvested, and cell lysates were assayed for firefly and Renilla luciferase activity. The data is expressed as fold induction of luciferase activity relative to the promoter alone and data presented are the mean of three independent experiments performed in duplicate.

highest concentration of $\mathrm{mdm} 2$ did not completely inhibit induction by $\mathrm{pRb}$. Promoter activity was still induced by 1.7 -fold in the presence of both $\mathrm{pRb}$ and $3 \mu \mathrm{g}$ $\mathrm{mdm} 2$, rather than repressed to the sub-basal levels observed with $\mathrm{Sp} 1 / \mathrm{mdm} 2$ co-expression.

To investigate whether this repression of the hTR promoter by $\mathrm{mdm} 2$ was entirely dependent on Sp1, we transfected a core promoter construct harboring functional mutations in all Sp1 binding sites. It should be noted the construct used here contains a shorter promoter fragment than that used throughout. Our previous study showed 
a)

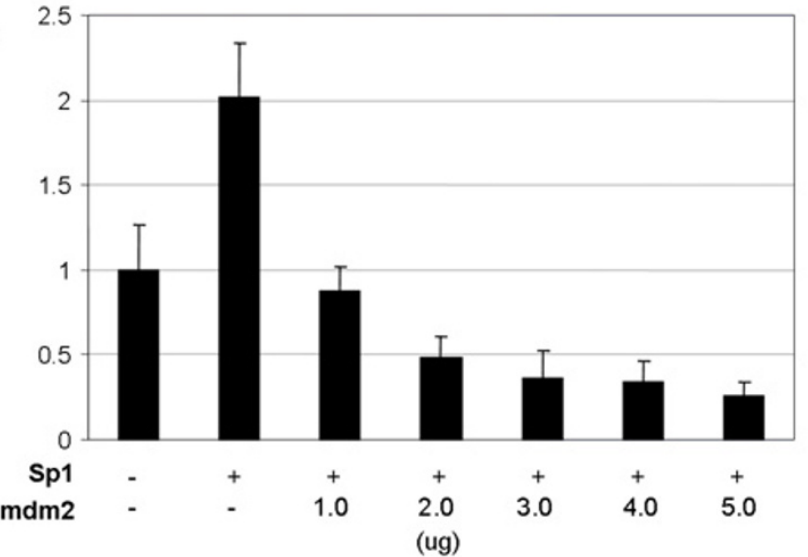

b)

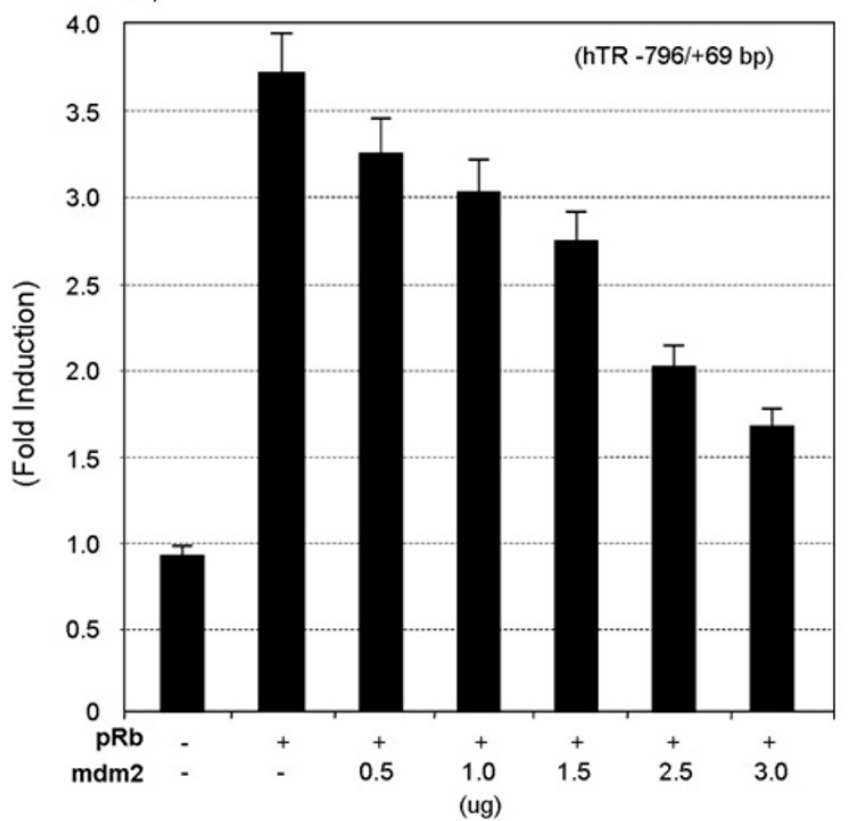

c)

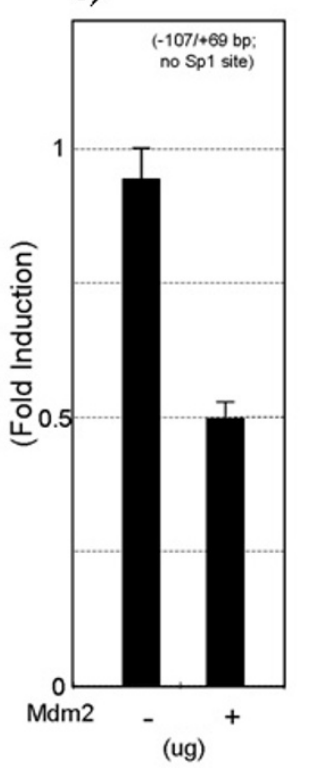

Figure 3

Mdm2 represses $p R b$ and SpI mediated $h T R$ promoter transactivation a) mdm2 suppresses Sp I activation of hTR promoter activity. 5637 cells were co-transfected with I.5 $\mu \mathrm{g}$ of the pLh2023(-796/+69) construct, $2.0 \mu \mathrm{g}$ of the expression vector for either Spl and a titration of $\mathrm{mdm} 2$. Total input DNA amount for transfection was adjusted with Salmon Sperm DNA to ensure a constant amount in all transfections. After 48 hour of culture, cells were harvested, and the cell lysates assayed for firefly and Renilla luciferase activity. The data is expressed as fold induction of luciferase activity relative to the promoter alone and data are the mean of three independent experiments performed in duplicate. b) $\mathbf{m d m} \mathbf{2}$ suppresses pRB activation of hTR promoter activity 5637 cells were co-transfected with I.5 $\mu \mathrm{g}$ of the pLh2023(-796/+69) construct, $2.0 \mu \mathrm{g}$ of the expression vector for either $\mathrm{pRb}$ and a titration of $\mathrm{mdm} 2$. Total input DNA amount for transfection was adjusted with Salmon Sperm DNA to ensure a constant amount in all transfections. After 48 hour of culture, cells were harvested, and the cell lysates assayed for firefly and Renilla luciferase activity. The data is expressed as fold induction of luciferase activity relative to the promoter alone and data are the mean of three independent experiments performed in duplicate. c) SpI sites in the hTR promoter are not essential for repression by $\mathbf{m d m} 25637$ cells were co-transfected with $3.0 \mu \mathrm{g}$ of the 2923 wild type or $2923 \mathrm{mSpl}$ (4) mutant constructs [13], together with mdm2. After 48 hour of culture, cells were harvested, and the cell lysate were assayed for firefly and Renilla luciferase activity. The data is expressed as fold induction of luciferase activity relative to the promoter alone and the means of the three independent experiments performed in duplicate. 


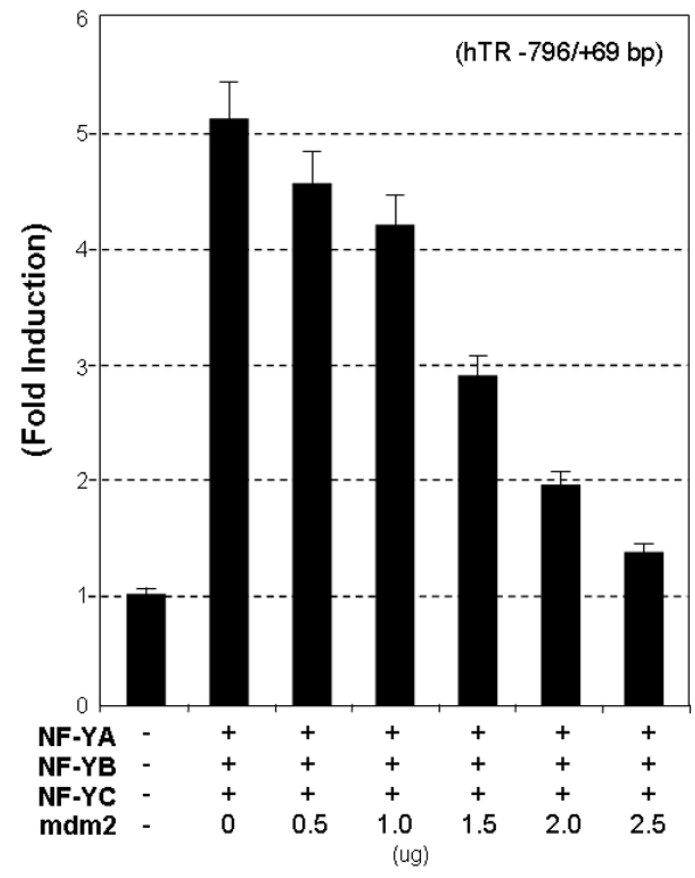

\section{Figure 4}

Mdm2 inhibits NF-Y mediated hTR transactivation. 5637 cells were co-transfected with I.5 $\mu \mathrm{g}$ of the pLh2023(796/+69) construct, $0.5 \mu \mathrm{g}$ of expression vectors encoding wild-type NF-YA, B and C together with increasing amounts of $\mathrm{mdm} 2$ expression vector (from 0 to $2.5 \mu \mathrm{g}$ ). Total input DNA amount for transfection was adjusted with Salmon Sperm DNA to ensure a constant amount in all transfections. After $\mathbf{4 8}$ hour of culture, cells were harvested, and the cell lysate were assayed for firefly and Renilla luciferase activity. The data is expressed as fold induction of luciferase activity relative to the promoter alone and the means of the three independent experiments performed in duplicate.

that mutation of all four Sp1 binding sites does not impair the activity of this hTR core promoter or its ability to be transactivated by NF-Y, but disrupts Sp1 binding and activation [13]. As shown in figure $3 \mathrm{C}, \mathrm{mdm} 2$ was also able to repress this mutant, indicating that $\mathrm{Sp} 1$ is not essential for mdm 2 mediated repression of the hTR promoter in vitro. Furthermore, gel shift analysis using a probe corresponding to the Sp1.3 site did not produce an mdm2 specific supershift, suggesting that mdm2 may not directly bind the hTR promoter DNA (data not shown).

\section{Mdm2 interferes with NF-Y-dependent activation of hTR promoter}

Since mdm 2 can influence the basal activity of the hTR reporter without targeting its Sp1 binding sites, it is likely that at least part of the repressive effect is directed through another pathway. One alternative mechanism by which mdm 2 could regulate the construct is through interfering with the NF-Y-CCAAT-box complex. Therefore, we next tested whether mdm2 could repress NF-Y function. As shown in Fig. 4, the hTR promoter is strongly stimulated (more than 5-fold induction) by co-transfection of expression vectors encoding the three NF-Y subunits, NF-YA, B and $\mathrm{C}$. Titration of $\mathrm{mdm} 2$ again resulted in dose-dependent inhibition of promoter induction, reducing NF-Y mediated activation to 1.4-fold relative to basal levels at the highest mdm 2 concentration. Thus, forced expression of mdm2 also attenuates NF-Y-activated transcription. This finding suggests that in addition to Sp1 dependent effects, down-regulation of hTR promoter activity by mdm2 may also be mediated partly by a mechanism involving inhibition of NF-Y-activated transcription.

\section{Discussion}

The retinoblastoma gene product $\mathrm{pRb}$ acts as a positive regulator of hTR promoter activity by an unknown mechanism while Sp1 and NF-Y activate the hTR promoter by directly binding to DNA. Recent studies have suggested that pRb can mediate stimulatory effects at Sp1 stimulated promoters by liberating Sp1 from negative regulation by mdm2 [15,21-23]. Mdm2 regulates the activities of both p53 and pRB, and physically interacts with $\mathrm{Sp} 1$ to repress transcription [24-26]. Conversely, pRB interaction with mdm2 displaces Sp1 and restores Sp1 DNA binding and transactivation activity. Additionally, mdm 2 protein activates the p53 pathway under stress conditions and also represses transcription directly by interaction with elements of the basal transcription machinery and their binding sites $[27,28]$.

In this study, we used the p53 and pRb negative bladder cancer cell line 5637 to provide evidence that mdm2 interacts with the hTR core promoter in vivo (figure 1) and serves as a negative regulator of the hTR gene promoter in vitro (figure 2). Mdm2 opposed $\mathrm{Sp} 1$ and $\mathrm{pRb}$ directed transactivation of the hTR promoter, suggesting a plausible mechanism whereby transfected $\mathrm{pRb}$ may elicit its effects by opposing the action of mdm2 (figure 3 ). The reciprocal scenario in which mdm 2 might oppose $\mathrm{pRB}$ cannot explain the negative effect of transfected mdm2 alone since the cells used here lack functional pRB. Rather, other mechanisms, probably including direct inhibition of Sp1 must be involved.

Mdm2 can bind directly to Sp1 and inhibit its DNA binding and can also bind to Sp1 sites at some promoters such as that of p65 [27]. Mdm2 suppressed Sp1 mediated transactivation in this study, but also had a more general repressive effect that cannot have been entirely dependent on inhibition of Sp1 since an hTR core promoter construct 


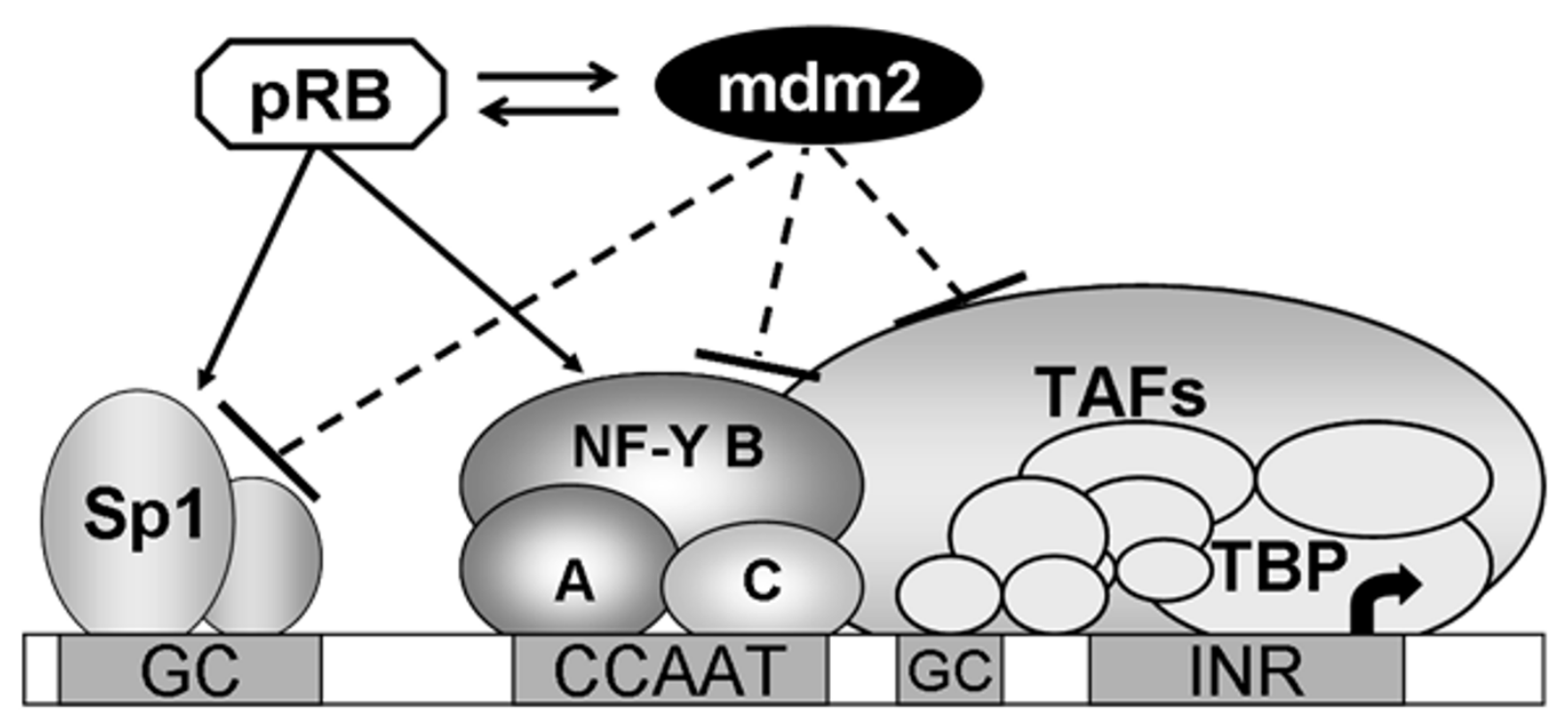

\section{Figure 5}

Multiple mechanisms of the transcriptional repression of the $\mathbf{h T R}$ gene by $\mathbf{m d m} \mathbf{2}$. Schematically shown are various mechanisms by which mdm2 might act on the hTR core promoter. The hTR core promoter elements include Spl sites (recognised by SpI family factors) and a CCAAT-box (recognized by NF-YA, B and C). NF-Y may facilitate the access of upstream activators (such as Spl) to their cognate enhancer/promoter sequences, recruit TAFs components of TFIID [33] and serve to instigate the formation of a pre-initiation complex of general transcription factors and Pol II. Co-regulators such as pRB/mdm2 for modulation of signals between transcription factors and the core transcriptional machinery might act through the hTR core promoter directly or indirectly.

carrying functional mutations in all Sp1 sites was still repressed by mdm2 (figure $3 \mathrm{C}$ ). This clearly argues against direct binding of mdm 2 to those sites and implies the existence of additional repressive mechanisms.

Here we demonstrated that activation of the hTR promoter by over-expression of all three sub-units of NF-Y could also be inhibited by mdm2 (figure 4 ). The CCAAT box binding protein NF-Y is a ubiquitous factor with central roles in PolII mediated transcription at numerous promoters. In cooperation with accessory proteins, NF-Y binds promoters in vivo before gene activation and "presets" the promoter architecture allowing access by other regulatory proteins. There is also increasing evidence that NF-Y recruits multiple components of the basal PolII machinery [29-33]. Mdm2 and $\mathrm{pRb}$ have also been reported to interact with the basal PolII transcriptional apparatus [28,34-36]. Therefore, the possibility exists that mdm 2 also inhibits this promoter through one of these other interactions although this remains to be tested (figure 5). Thus either an interaction with the basal transcriptional machinery or specific transcription factors may regulate hTR promoter activity.

\section{Conclusions}

In conclusion, the hTR promoter is dominantly suppressed by mdm2. Mdm2 may utilise more than one mechanism to attenuate hTR promoter activity (Fig. 5). Mdm2 may directly repress activation by both $\mathrm{pRB}$ and Sp1, or activation by NF-Y. Furthermore, the ability of mdm 2 to interact and interfere with components of the general transcription machinery might partly explain the general repressive effect seen here. Elucidation of new regulators affecting hTR basal promoter activity in cancer cells provides a basis for future studies aimed at improving our understanding of the differential hTR expression between normal and cancer cells. This will be essential for a thorough understanding of the regulation of telomerase 
and for advancement of telomerase directed gene therapies.

\section{Competing interests}

The author(s) declare that they have no competing interests.

\section{Authors' contributions}

$\mathrm{JZ}, \mathrm{AB}$ and $\mathrm{KJ}$ carried out the transfection and genetic analysis. $\mathrm{AB}$ helped draft the manuscript. WNK conceived the study, participated in design and coordination and helped draft the manuscript. All authors read and approved the final manuscript.

\section{Acknowledgements}

This work was supported by the Cancer Research UK and Glasgow University.

\section{References}

I. Bachand F, Autexier C: Functional regions of human telomerase reverse transcriptase and human telomerase RNA required for telomerase activity and RNA-protein interactions. Mol Cell Biol 200I, 2 I: I888-1897.

2. Autexier C, Pruzan R, Funk WD, Greider CW: Reconstitution of human telomerase activity and identification of a minimal functional region of the human telomerase RNA. Embo J 1996, 15:5928-5935.

3. Hoare SF, Bryce LA, Wisman GB, Burns S, Going IJ, van der Zee AG, Keith WN: Lack of telomerase RNA gene hTERC expression in alternative lengthening of telomeres cells is associated with methylation of the hTERC promoter. Cancer Res 200I, 6I:27-32.

4. Kilian A, Bowtell DD, Abud HE, Hime GR, Venter DJ, Keese PK, Duncan EL, Reddel RR, Jefferson RA: Isolation of a candidate human telomerase catalytic subunit gene, which reveals complex splicing patterns in different cell types. Hum Mol Genet 1997, 6:2011-2019.

5. Meyerson M, Counter CM, Eaton EN, Ellisen LW, Steiner P, Caddie SD, Ziaugra L, Beijersbergen RL, Davidoff MJ, Liu Q, Bacchetti S, Haber DA, Weinberg RA: hEST2, the putative human telomerase catalytic subunit gene, is up- regulated in tumor cells and during immortalization. Cell 1997, 90:785-795.

6. Nakamura TM, Morin GB, Chapman KB, Weinrich SL, Andrews WH, Lingner J, Harley CB, Cech TR: Telomerase catalytic subunit homologs from fission yeast and human [In Process Citation]. Science 1997, 277:955-959.

7. Abdul-Ghani R, Ohana P, Matouk I, Ayesh S, Ayesh B, Laster M, Bibi O, Giladi H, Molnar-Kimber K, Sughayer MA, de Groot N, Hochberg A: Use of transcriptional regulatory sequences of telomerase (hTER and hTERT) for selective killing of cancer cells. Mol Ther 2000, 2:539-544.

8. Bilsland AE, Anderson CJ, Fletcher-Monaghan AJ, McGregor F, Jeffry Evans TR, Ganly I, Knox RJ, Plumb JA, Nicol Keith W: Selective ablation of human cancer cells by telomerase-specific adenoviral suicide gene therapy vectors expressing bacterial nitroreductase. Oncogene 2003, 22:370-380.

9. Gu J, Andreeff M, Roth JA, Fang B: hTERT promoter induces tumor-specific Bax gene expression and cell killing in syngenic mouse tumor model and prevents systemic toxicity. Gene Ther 2002, 9:30-37.

10. Plumb JA, Bilsland A, Kakani R, Zhao J, Glasspool RM, Knox RJ, Evans TR, Keith WN: Telomerase-specific suicide gene therapy vectors expressing bacterial nitroreductase sensitize human cancer cells to the pro-drug CBI954. Oncogene 200I, 20:7797-7803.

II. Majumdar AS, Hughes DE, Lichtsteiner SP, Wang Z, Lebkowski JS, Vasserot AP: The telomerase reverse transcriptase promoter drives efficacious tumor suicide gene therapy while preventing hepatotoxicity encountered with constitutive promoters. Gene Ther 200I, 8:568-578.
12. Zhao JQ, Glasspool RM, Hoare SF, Bilsland A, Szatmari I, Keith WN: Activation of telomerase rna gene promoter activity by NF$\mathrm{Y}, \mathrm{SpI}$, and the retinoblastoma protein and repression by Sp3. Neoplasia 2000, 2:53I-539.

13. Zhao J, Bilsland A, Hoare SF, Keith WN: Involvement of NF-Y and SpI binding sequences in basal transcription of the human telomerase RNA gene. FEBS Lett 2003, 536: I I I-I I9.

14. Keith WN, Tom Vulliamy, Jiangqin Zhao, Can Erzik, Alan Bilsland, Cem Ar, Birsen Ulku, Anna Marrone, Philip J Mason, Monica Bessler, Nedime Serakinci, Inderjeet Dokal: A mutation in a functional Sp I binding site of the telomerase RNA gene (hTERC) promoter in a patient with Paroxysmal Nocturnal Haemoglobinuria. BMC Blood Disord 2004, 4:3.

15. Johnson-Pais T, Degnin C, Thayer MJ: pRB induces Sp I activity by relieving inhibition mediated by MDM2. Proc Natl Acad Sci U S A 200I, 98:22II-22I6.

16. Rieger KM, Little AF, Swart JM, Kastrinakis WV, Fitzgerald JM, Hess DT, Libertino JA, Summerhayes IC: Human bladder carcinoma cell lines as indicators of oncogenic change relevant to urothelial neoplastic progression. $\mathrm{Br}$ / Cancer 1995, 72:683-690.

17. Zhao JQ, Hoare SF, McFarlane R, Muir S, Parkinson EK, Black DM, Keith WN: Cloning and characterization of human and mouse telomerase RNA gene promoter sequences. Oncogene 1998 , 16:1345-I350.

18. Mantovani R, Li XY, Pessara U, Hooft van Huisjduijnen R, Benoist $C$, Mathis D: Dominant negative analogs of NF-YA. J Biol Chem 1994, 269:20340-20346.

19. Boyd KE, Wells J, Gutman J, Bartley SM, Farnham PJ: c-Myc target gene specificity is determined by a post-DNAbinding mechanism. Proc Natl Acad Sci U S A 1998, 95: 13887-1 3892.

20. Lin SY, Black AR, Kostic D, Pajovic S, Hoover CN, Azizkhan JC: Cell cycle-regulated association of E2FI and $\mathrm{SpI}$ is related to their functional interaction. Mol Cell Biol 1996, 16:1668-1675.

21. Kim SJ, Onwuta US, Young Ik L, Li R, Botchan MR, Robbins PD: The retinoblastoma gene product regulates SpI-mediated transcription. Molecular \& Cellular Biology I 992, I 2:2455-2463.

22. Udvadia AJ, Rogers KT, Higgins PD, Murata Y, Martin KH, Humphrey PA, Horowitz JM: Sp-I binds promoter elements regulated by the RB protein and Sp-I- mediated transcription is stimulated by RB coexpression. Proc Natl Acad Sci U S A 1993, 90:3265-3269.

23. Guo CS, Degnin C, Fiddler TA, Stauffer D, Thayer MJ: Regulation of MyoD Activity and Muscle Cell Differentiation by MDM2, pRb, and SpI.J Biol Chem 2003, 278:226I5-22622.

24. Momand J, Jung D, Wilczynski S, Niland J: The MDM2 gene amplification database. Nucleic Acids Res 1998, 26:3453-3459.

25. Xiao ZX, Chen J, Levine AJ, Modjtahedi N, Xing J, Sellers WR, Livingston DM: Interaction between the retinoblastoma protein and the oncoprotein MDM2. Nature 1995, 375:694-698.

26. Piette J, Neel H, Marechal V: Mdm2: keeping p53 under control. Oncogene 1997, 15:1001-1010.

27. Gu L, Findley HW, Zhou M: MDM2 induces NF-kappaB/p65 expression transcriptionally through $\mathrm{Spl}$ - binding sites: a novel, p53-independent role of MDM2 in doxorubicin resistance in acute lymphoblastic leukemia. Blood 2002, 99:3367-3375.

28. Thut CJ, Goodrich JA, Tjian R: Repression of p53-mediated transcription by MDM2: a dual mechanism. Genes Dev 1997, I I:1974-1986.

29. Bennett MK, Osborne TF: Nutrient regulation of gene expression by the sterol regulatory element binding proteins: increased recruitment of gene-specific coregulatory factors and selective hyperacetylation of histone $\mathbf{H} 3$ in vivo. Proc Natl Acad Sci U S A 2000, 97:6340-6344.

30. Imbriano C, Bolognese F, Gurtner A, Piaggio G, Mantovani R: HSP. CBF is an NF-Y-dependent coactivator of the heat shock promoters CCAAT boxes. I Biol Chem 200I, 276:26332-26339.

3I. Bellorini M, Lee DK, Dantonel JC, Zemzoumi K, Roeder RG, Tora L, Mantovani R: CCAAT binding NF-Y-TBP interactions: NF-YB and NF-YC require short domains adjacent to their histone fold motifs for association with TBP basic residues. Nucleic Acids Research 1997, 25:2174-2181.

32. Caretti G, Salsi V, Vecchi C, Imbriano C, Mantovani R: Dynamic recruitment of NF-Y and hats on cell-cycle prometers. J Biol Chem 2003, 278:30435-30440. 
33. Frontini M, Imbriano C, diSilvio A, Bell B, Bogni A, Romier C, Moras D, Tora L, Davidson I, Mantovani R: NF-Y recruitment of TFIID, multiple interactions with histone fold TAF(II)s. J Biol Chem 2002, 277:584|-5848.

34. Leveillard T, Wasylyk B: The MDM2 C-terminal region binds to TAFII250 and is required for MDM2 regulation of the cyclin A promoter. J Biol Chem 1997, 272:3065I-3066I.

35. Shao Z, Ruppert S, Robbins PD: The retinoblastoma-susceptibility gene product binds directly to the human TATA-binding protein-associated factor TAFII250. Proc Natl Acad Sci U S A 1995, 92:3115-3119.

36. Buschmann T, Lin Y, Aithmitti N, Fuchs SY, Lu H, Resnick-Silverman L, Manfredi JJ, Ronai Z, Wu X: Stabilization and activation of p53 by the coactivator protein TAFII3I. J Biol Chem 200I, 276: | 3852-I3857.

\section{Pre-publication history}

The pre-publication history for this paper can be accessed here:

http://www.biomedcentral.com/1471-2407/5/6/prepub

Publish with Bio Med Central and every scientist can read your work free of charge

"BioMed Central will be the most significant development for disseminating the results of biomedical research in our lifetime. "

Sir Paul Nurse, Cancer Research UK

Your research papers will be:

- available free of charge to the entire biomedical community

- peer reviewed and published immediately upon acceptance

- cited in PubMed and archived on PubMed Central

- yours - you keep the copyright

Submit your manuscript here:

http://www.biomedcentral.com/info/publishing_adv.asp 